\title{
Ground motion and tectonics in the Terceira Island: Tectonomagmatic interactions in an oceanic rift (Terceira Rift, Azores Triple Junction)
}

\author{
F.O. Marques ${ }^{\mathrm{a}, \star}$, J. Catalão $^{\mathrm{b}}$, A. Hilden brand ${ }^{\mathrm{c}, \mathrm{d}}$, P. Madureira ${ }^{\mathrm{e}, \mathrm{f}}$ \\ ${ }^{a}$ Universidade de Lisboa, Lisboa, Portugal \\ ${ }^{\mathrm{b}}$ IDL Universidade de Lisboa, Lisboa, Portugal \\ c Université Paris-Sud, Laboratoire GEOPS, UMR8 148, Orsay, F-91405, France \\ d CNRS, Orsay, F-91405, France

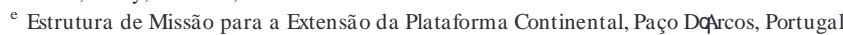 \\ ${ }^{\text {f }}$ Centro de Geofísica de Évora and Dep. Geociências da Univ. de Évora, Évora, Portugal
}

\section{a r t i c l e i n f o}

\section{Article history:}

Received 30 September 2014

Received in revised form 13 February 2015

Accepted 16 February 2015

Available online 25 March 2015

\section{Keywords:}

Terceira Island

Terceira Rift

Azores Triple Junction

GPS and tectonics

Internal deformation

\begin{abstract}
a b s t r a c t
The interpretation of high-resolution topography/bathymetry, GPS and InSAR data, and detailed structural geology indicate that: (1) Terceira developed at the intersection of two major volcano-tectonic lineaments: WNW-ESE (local TR's direction) and NNW-SSE (submarine chain of volcanoes, here firstly recognised and coined Terceira Seamount Chain). (2) Terceira is affected by four main fault systems: the ca. N165 (normal faults dipping to east and west, mostly across the middle of the island), the $\mathrm{N} 140^{\circ}$ (normal faults mostly making up the Lajes Graben), the $\mathrm{N} 110^{\circ}$ (faults with oblique striations ï normal dextral, making up the main volcanic lineament), and the more subtle $\mathrm{N}^{\circ} 0^{\circ}$ (the transform direction related to the Nubia/Eurasia plate boundary). Seismicity, GPS data and faults displacing the topography indicate that all systems are active. (3) The whole island is subsiding at a rate of ca. $5 \mathrm{~mm} / \mathrm{yr}$, as attested by both GPS and In SAR data, which is exceptionally high for the Azores islands. Common explanations like thermal contraction, or bending of the lithosphere, or magmatic processes, or collapse of the island under its own weight likely cannot justify the observed subsidence rate. The estimated average of TR's subsidence rate is also not enough, therefore we conclude that the measured $5 \mathrm{~mm} / \mathrm{yr}$ can be a peak. (4) The fault geometry and kinematics are consistent with the current direction of maximum extension in the Azores (ca. $\mathrm{N}^{\circ}$ ), and the rotation of Nubia relative to Eurasia. (5) Given that the NEshoulder of the Lajes Graben is moving upwards at $5 \mathrm{~mm} / \mathrm{yr}$ and sits directly on the TR's NE shoulder, we conclude that the TR's shoulder is moving up, most likely as a result of the elastic rebound associated with rifting. The elastic rebound in both NEand SW TR's shoulders is most likely responsible for the observed ridge morphology all along the TR.
\end{abstract}

() 2015 Elsevier B.V. All rights reserved.

\section{Introduction}

The location and evolution of volcanic islands inside active oceanic rifts are still matters of great debate. Here we use Terceira Island, which has developed inside the Terceira Rift (TR), to bring light to some relevant problems that still require explanation: (1) What is Terceira's current ground motion, and what information can we retrieve regarding internal deformation of the volcanic edifice, and meaning of the rigid body motion? (2) What is the meaning of the vertical component of Terceira's motion? (3) How are internal tectonics and volcanism organised, and what is their relationship to large-scale tectonics? (4) How can the in ternal deformation give relevant inform ation regarding the external deform ation and far field stresses? (5) Why has volcanism concentrated to form islands, like Terceira, in side the TR? (6) How

\footnotetext{
* Corresponding author. Tel.: + 351217500000 ; fax: + 351217500064 .

E-mail address: fomarques@fc.ul.pt (F.O. Marques).
}

does the island relate to the elongated volcanic ridges and islands subparallel to, and SW of the TR?

McKenzie (1972) showed that the Azores-Gibraltar plate boundary results from differential spreading rates of Eurasia (Eu) and Nubia (Nu) relative to North America (NA), thus transforming the MidAtlantic Rift (MAR) spreading into compression in the Mediterranean Alpide Belt. Based on the kinematics of Eu and $\mathrm{Nu}$, and on earthquake fault plane solutions, McKenzie (1972) concluded that, presently, the western end of the Azores-Gibraltar plate boundary is dilatational from the MAR-axis to the Gloria Fault, whereas the Gloria Fault is dextral transcurrent, and close to Iberia the Eu/Nu boundary becomes compressional.

The current plate kinematics (DeMets et al., 2010) shows that the MAR is opening faster north (NA/Eu boundary) than south of the Azores Triple Junction ( ATJ) (NA/Nu boundary) (Fig. 1). Moreover, there is also an angular difference, which in duces extension in the Azores region, between the Gloria Fault and the MAR. The rotation of Nu relative to Eu 